This is the author's final, peer-reviewed manuscript as accepted for publication. The publisher-formatted version may be available through the publisher's web site or your institution's library.

\title{
Exposure of prepubertal beef bulls to cycling females does not enhance sexual development
}

N. A. Miller and K. E. Fike

\section{How to cite this manuscript}

If you make reference to this version of the manuscript, use the following information:

Miller, N. A., \& Fike, K. E. (2014). Exposure of prepubertal beef bulls to cycling females does not enhance sexual development. Retrieved from http://krex.ksu.edu

\section{Published Version Information}

Citation: Miller, N. A., \& Fike, K. E. (2014). Exposure of prepubertal beef bulls to cycling females does not enhance sexual development. Theriogenology, 82(3), 447-454.

Copyright: Published by Elsevier Inc.

Digital Object Identifier (DOI): doi:10.1016/j.theriogenology.2014.05.001

Publisher's Link: http://www.theriojournal.com/article/S0093-691X(14)00207-6/abstract

This item was retrieved from the K-State Research Exchange (K-REx), the institutional repository of Kansas State University. K-REx is available at http://krex.ksu.edu 
REVISED

Exposure of prepubertal beef bulls to cycling females does not enhance sexual development

$$
\text { N.A. Miller }{ }^{1} \text { and K.E. Fike* }
$$

Department of Animal Science and Industry, Kansas State University, Manhattan, Kansas, USA

${ }^{1}$ Present address: Certified Angus Beef LLC, 206 Riffel Road, Wooster, Ohio 44691, USA.

Email address: nmiller@certifiedangusbeef.com

*Corresponding author: Tel.: +1 785532 1104; Fax: +1 785532 7059. Email address:

karol@,ksu.edu (K.E. Fike) 


\section{Abstract}

The objective of this study was to determine whether continuous, long-term, fenceline exposure of prepubertal beef bulls to cycling beef females reduced age at puberty and influenced the percentage of bulls that passed an initial breeding soundness examination (BSE). Bulls (Angus, $\mathrm{N}=37$; Simmental, $\mathrm{N}=22$; Hereford, $\mathrm{N}=10$; Simmental $\mathrm{x}$ Angus, $\mathrm{N}=8$ ) averaging $202 \pm 21.5 \mathrm{~d}$ of age were given either continuous fenceline and visual exposure to cycling females (Exposed: $\mathrm{N}=41$ ) or no exposure (Control: $\mathrm{N}=36$ ). Estrus was induced in cycling beef females so at least 3 females were in standing estrus each week during the $182 \mathrm{~d}$ of exposure to bulls. Scrotal circumference (SC), body weight, and blood samples were collected every $28 \mathrm{~d}$. When bulls had SC $\geq 26 \mathrm{~cm}$, semen samples were obtained monthly via electroejaculation until puberty was achieved $\left(\geq 50 \times 10^{6} \mathrm{sperm} / \mathrm{mL}\right.$ with at least $10 \%$ progressive motility). Behavioral observations were conducted twice monthly, once when females were in estrus and once during diestrus. Homosexual mounting, flehmen responses, and number of times near penned females were recorded for each observation period. Breeding soundness examinations were conducted when bulls averaged $364 \pm 21.5 \mathrm{~d}$ of age. Normal sperm morphology of at least $70 \%$ and sperm motility of at least $30 \%$ were required to pass the BSE. Age, body weight, and SC at puberty did not differ between Exposed and Control bulls $(320 \pm 28 \mathrm{~d}$ and $311 \pm 29 \mathrm{~d} ; 466.2 \pm 12.2$ and $437.7 \pm 13.5 \mathrm{~kg}$; and $34.4 \pm 2.5 \mathrm{~cm}$ and $34.9 \pm 2.5 \mathrm{~cm}$, respectively). Percentage of bulls passing their initial BSE did not differ between treatments (Exposed: 87.8\%, Control: 75.0\%). Treatment, month, and female estrous stage interacted $(\mathrm{P}=0.05)$ to affect the number of mount attempts and flehmen responses. Exposed bulls entered the cow area more times $(\mathrm{P}<0.001)$ during estrus than diestrus in months one, two and three. We concluded that bulls given 
continuous, long-term, fenceline exposure to cycling beef females do not have enhanced sexual development.

Key words: beef bull, behavior, breeding soundness examination, female exposure, puberty, sexual development

\section{Introduction}

Age at puberty is a crucial factor influencing a young bull's ability to pass a breeding soundness examination (BSE) at a year of age, and reducing that age may prove beneficial to beef producers. Researchers have established that beef females can achieve puberty at earlier ages and reduced duration of postpartum anestrus when exposed to mature bulls [1-3] and puberty is hastened in prepubertal gilts when exposed to boars [4].

Across species, pheromones secreted in urine, feces, and glands have been shown to influence the female reproductive system via phermonal detection by the vomeronasal organ and subsequent effects on the hypothalamic-pituitary-gonadal axis $[5,6]$. Pheromones may act alone in combination with visual, auditory, and (or) tactile cues [5] such as mounting activity, vocalization, licking, and nuzzling though potential effects of non-pheromonal cues largely remain to be delineated.

Considering both potential pheromonal and non-pheromonal effects, few studies have evaluated the effects of female exposure on bovine male sexual development. Price and Wallach [7] reported that bulls with exposure to females (weaning to 18 mo of age) exhibiting estrus at various times throughout the study did not have advantage over nonexposed bulls in their sexual performance at an older age. Sexual stimulation prior to semen collection is well documented to enhance sperm output by bulls $[8,9]$ and widely used in the commercial AI industry. Similarly, 
Geary and Reeves [10] reported that bulls use visualization rather than olfaction as the primary and preferred way to detect estrus in females.

Our hypothesis was that continuous, long-term visual and fenceline exposure of young beef bulls to cycling females would accelerate the pubertal process, and thus increase the percentage of bulls passing their first BSE at approximately $1 \mathrm{y}$ of age. Objectives were to: 1) determine if continuous, long-term, fenceline exposure of prepubertal beef bulls to mature beef females exhibiting estrous cycles influence age at puberty, and 2) quantify the percentage of exposed bulls passing their initial BSE compared with bulls not exposed to cycling females. In addition, we determined how estrual females affected bull sexual behaviors such as bull mounting and flehman response incidence.

\section{Materials and Methods}

This study was conducted at the Kansas State University Purebred Beef Teaching Unit in accordance with and approval of the Kansas State University Institutional Animal Care and Use Committee (IACUC). Seventy-nine bulls (Angus, $\mathrm{N}=39$; Simmental, $\mathrm{N}=22$; Hereford, $\mathrm{N}=10$; Simmental x Angus, $\mathrm{N}=8$ ) at an average age of $202 \mathrm{~d} \pm 21.5 \mathrm{~d}$ at treatment onset were used in

this study. Bulls were weaned $10 \mathrm{~d}$ before onset of the study, grouped by breed and stratified by age within breed, then assigned randomly to one of two treatments: 1) continuous fenceline and visual contact with beef females exhibiting estrous cycles (Exposed; $\mathrm{N}=41$ ); or 2) no visual or fenceline contact with beef females (Control; $\mathrm{N}=38$ ). Two control bulls (one Angus and one Simmental) were removed from the study; one had only one testicle, and the other was a carrier of a genetic defect. Hence, 41 bulls ( $\mathrm{n}=20$ and 21 bulls per pen) were in the Exposed treatment (Angus, $\mathrm{N}=18$; Simmental, $\mathrm{N}=10$; Hereford, $\mathrm{N}=5$; Simmental $\mathrm{x}$ Angus, $\mathrm{N}=3$ ), and $36(\mathrm{n}=$ 17 and 19 bulls per pen) served as Controls (Angus, $\mathrm{N}=20$; Simmental, $\mathrm{N}=11$; Hereford, $\mathrm{N}=$ 
5; Simmental x Angus, $\mathrm{N}=5$ ). Exposure to cycling females began on d 0 and continued through the second BSE at Day 182 of the study.

\subsection{Bull Management}

Bulls were housed in four $97.6 \mathrm{~m}$ x $42.7 \mathrm{~m}$ adjacent pens. A 3.4-m-high plywood wall served as a visual barrier between the exposed and control bulls, thus preventing the control bulls from observing the cycling beef females (minimum of $42.7 \mathrm{~m}$ from control bulls to penned females). Cycling females were housed in a $54.9 \times 10.6-\mathrm{m}$ pen located within one of the two pens of exposed bulls such that all exposed bulls had a minimum of 54.9 linear $\mathrm{m}$ of fenceline exposure facilitating continual visual and nose-to-nose contact with cycling females during the study. Dietary rations for bulls were consisted of four ration phases: a starter diet $(46.3 \%$ wet corn gluten, $44.7 \%$ prairie hay, $2.4 \%$ flaked corn) was fed for $10 \mathrm{~d}$ from weaning to onset of the study and the first $11 \mathrm{~d}$ of the study; a grower diet (47.5\% wet corn gluten, $34.7 \%$ prairie hay, $15.3 \%$ flaked corn) was fed for the next 70 days; a finisher diet (44.6\% wet corn gluten, $24.5 \%$ prairie hay, $28.5 \%$ flaked corn) was then fed for the 61 days. The trial concluded with the grower diet for the final $39 \mathrm{~d}$ of the study. Diets were formulated for bulls to achieve an approximate ADG of $1.6 \mathrm{~kg}$.

\subsection{Female Management}

Beef females $(\mathrm{N}=9)$ that continued to exhibit estrous cycles were divided into 2 groups $(\mathrm{N}=4$ or 5$)$ for use in this study and all females were in visual and fenceline contact with bulls throughout the duration of the study. Transrectal ultrasound was performed and presence of a CL was confirmed to ensure that females were exhibiting estrous cycles before beginning the study. Females with a CL at the time of the ultrasound were administered $500 \mu \mathrm{g}$ of cloprostenol (EstroPLAN, Agri Laboratories, Ltd., St. Joseph, MO, USA) im to cause luteolysis and bring females into estrus. All other females without a CL were subjected to an initial estrous 
synchronization protocol before the study in which a $100 \mu \mathrm{g} \mathrm{GnRH}$ (Factrel, $2 \mathrm{~mL}$, Fort Dodge Animal Health, Overland Park, KS, USA) was given in conjunction with insertion of an intravaginal controlled internal drug release (Eazi-Breed CIDR; Zoetis, Madison, NJ, USA) insert for $5 \mathrm{~d}$. Upon removal of the CIDR, $500 \mu \mathrm{g}$ cloprostenol was given im to cause luteolysis and bring females into estrus. After this initial synchronization of estrus, each week beginning on Day 0 , a group $(\mathrm{N}=4$ or 5$)$ of females were estrus-synchronized using an im injection of $500 \mu \mathrm{g}$ of cloprostenol and the second group was synchronized the following week. On Day 46 of the study, seven of the original nine females were replaced with females that had been confirmed to be exhibiting estrous cycles. The pattern of weekly estrus synchronization continued throughout the study. A combination of ESTROTECT patches (Rockway, Inc., Spring Valley, WI, USA) and visual observation were used to detect females in estrus each week to confirm that females exhibited standing estrus behavior. Each week, a minimum of three of the females in the group were confirmed to be in standing estrus. Synchronization of estrus continued through completion of the study (Day 182).

\subsection{Body Weights, Scrotal Circumference, and Blood Sampling}

An initial body weight, scrotal circumference (SC), and blood sample was collected $3 \mathrm{~d}$ before onset of treatment (Day -3). On Day 0, exposure to cycling females began, and a second body weight, SC, and blood sample was collected on Day 9 and repeated every $28 \mathrm{~d}$ until Day 149 of the study. Scrotal circumference was measured using a standard scrotal measuring tape by pulling the testicles to the bottom of the scrotum and measuring the largest circumference. Blood samples were collected via jugular puncture between 0700 and $1200 \mathrm{~h}$ each sampling day to assess testosterone concentrations. One 5-mL blood sample was collected from each bull and allowed to coagulate at $5^{\circ} \mathrm{C}$ for $12 \mathrm{~h}$ overnight. Samples were centrifuged approximately $24 \mathrm{~h}$ 
post-collection at $1,000 \mathrm{x}$ f for $15 \mathrm{~min}$ in a refrigerated centrifuge at $5^{\circ} \mathrm{C}$ to harvest serum. Serum was stored at $-20^{\circ} \mathrm{C}$ until assayed.

\subsection{Radioimmunoassay}

Concentrations of testosterone in blood serum were measured by direct quantitative (nonextracted) radioimmunoassay using Coat-A-Count testosterone kits (Catalog \#TKTT; Siemens Medical Solutions Diagnostics, Los Angeles, CA) validated for bovine serum. The antibody (supplied by the manufacturer) did not cross-react with aldosterone, 11-deoxycortisol, prednisone, progesterone, or spironolactone. Crossreactivity of the antibody was $<3.4 \%$ for 5 beta-androstan-3 $\alpha$, 17-beta-diol, androstenedione, $5 \alpha$-dihydrotestosterone, 4-estren-7 $\alpha$-methyl17-beta-ol-3-1, ethisterone, methyltestosterone, and 11-beta-hydroxytestosterone. Kit standards $(0.04,0.08,0.16,0.96,4.14,7.92$, and $16.85 \mathrm{ng} / \mathrm{mL})$, unknowns, and assay pools were added $\left(100 \mu \mathrm{L}\right.$ each) in duplicate to antibody-coated tubes. One $\mathrm{mL}$ of ${ }^{125} \mathrm{I}$ labeled testosterone was added to each tube, vortexed for $5 \mathrm{~s}$, and incubated overnight at $4^{\circ} \mathrm{C}$. The next day, tubes were decanted, blotted on paper towels, and radioactivity of each tube was quantified for $1 \mathrm{~min}$ in a gamma counter. Average assay sensitivity was $0.03 \mathrm{ng} / \mathrm{mL}$. Inter- and intra-assay coefficients of variation for 5 assays were $6.49 \%$ and $3.90 \%$, respectively, for a pooled serum sample that averaged $6.98 \pm 0.28 \mathrm{ng} / \mathrm{mL}$.

\subsection{Semen Collection and Evaluation}

Beginning when bulls had obtained $\mathrm{SC} \geq 26 \mathrm{~cm}$, a semen sample was obtained via electroejaculation using a SireMaster Professional electronic ejaculator (SireMaster, Manhattan, KS) with a $6.35-\mathrm{cm}$-diameter probe (SireMaster, Manhattan, KS). Semen collection continued

monthly until the bull achieved puberty $\left(50 \times 10^{6} \mathrm{sperm} / \mathrm{mL}\right.$ of ejaculate with $\geq 10 \%$ motility). Bulls were transported on a livestock trailer (approximately $4 \mathrm{~km}$ for $5 \mathrm{~min}$ one way) for all 
semen collections and evaluations conducted at the Kansas Artificial Breeding Services Unit. Sperm concentration was assessed using a NucleoCounter SP-100 (Chemometec, Denmark). Sperm motility was analyzed under a microscope (Olympus CX41, Center Valley, PA) at x 20 magnification. Morphology was analyzed at x 40 magnification. Bulls were considered pubertal if they achieved: 1) $\geq 26 \mathrm{~cm} \mathrm{SC}$, 2) $50 \times 10^{6} \mathrm{sperm} / \mathrm{mL}$ of ejaculate, and 3) $\geq 10 \%$ progressive motility. When all criteria for puberty were met, semen collections ceased until BSEs were conducted on Day 163, when bulls averaged $363 \pm 21.5 \mathrm{~d}$ of age.

\subsection{Breeding Soundness Examinations}

Breeding soundness examinations were conducted by a veterinarian. Semen samples were obtained from all bulls via electroejaculation, regardless of whether they had previously achieved puberty. Sperm motility and morphology were assessed under x 20 and x 40 magnification, respectively. Bulls passed their BSE if their semen sample had at least $30 \%$ progressive motility and a minimum $70 \%$ normal morphology in addition to all other BSE criteria, including an acceptable SC $(>30 \mathrm{~cm})$ for their age [11]. Bulls that did not meet these minimum criteria at the initial examination were retested $20 \mathrm{~d}$ later.

\subsection{Bull Behavior Assessments}

Assessments of bull behavior were conducted twice monthly when cycling females were in estrus and in diestrus. Each day of assessment consisted of three, 1-h observation periods (approximately 0700,1200 , and $1800 \mathrm{~h}$ ). Bulls were fed twice daily at approximately 0830 and 1630, ample time before and following behavior assessments in the morning and late afternoon, respectively. The number of mounting attempts and flehmen responses were recorded for all bulls in each pen. Mounting attempts were defined as any movement by a bull toward another bull in which both front feet were raised from the ground and contact was made between bulls. In 
addition to these behaviors, exposed bulls were also assessed for the number of times they entered a specified cycling female bovine area, which was defined as $3.05 \mathrm{~m}$ from each side of the cow pen, during each hour of observation. Behaviors were summed over the three, 1-h assessments for each observation period.

\subsection{Statistical Analysis}

All statistical analyses were conducted using procedures in SAS (version 9.2, SAS Inst. Inc., Cary, NC), with nonsignificant variables removed from the model (i.e., breed). Age, body weight, SC, and semen characteristics at puberty, as well as all repeated measures (body weight, SC, and testosterone concentrations), were analyzed using the mixed model procedure in SAS, with fixed effect of treatment and random effects of pen within treatment and animal by pen within treatment; therefore, clustering within pen was accounted for by the random effect of pen within treatment and animal by pen within treatment. Breeding soundness data were analyzed using the general linearized mixed model (GLIMMIX) procedure in SAS, with fixed effects of age at time of BSE, treatment, and their interactions and random effect of pen within treatment. Behavior data were analyzed using the mixed model procedure in SAS, including treatment, month of assessment, and stage of estrous cycle, as well as their interactions, as fixed effects. Random effects were pen, animal by pen within treatment and animal by month by pen within treatment. When interactions regarding behavior data were significant, the LSMEANS statement and SLICE option were used to generate and compare means within a specific month. The SATTERTHWAITE option was used in all mixed model analyses to determine the denominator degrees of freedom for test of fixed effects. A P-value of $\leq 0.05$ was considered significant, and $0.05<\mathrm{P}$-values $\leq 0.10$ were considered tendencies.

\section{Results}


Treatment and day interacted $(\mathrm{P}=0.0003)$ to affect bull body weight. Bull body weights at $\mathrm{d} 0$ were similar $(\mathrm{P}=0.24 ; 260.2 \pm 7.4$ and $247.3 \pm 7.9 \mathrm{~kg}$, respectively; mean $\pm \mathrm{SEM})$ for exposed and control bulls. Exposed bulls were heavier $(\mathrm{P}=0.02)$ at $\mathrm{d} 149$ of the study than control bulls ( $510.2 \pm 7.4 \mathrm{~kg}$ and $485.5 \pm 7.9 \mathrm{~kg}$, respectively). There was no treatment by day interaction nor treatment effect on scrotal circumference. Treatment and day interacted $(\mathrm{P}=$ 0.03) to affect testosterone concentrations (Fig. 1). Testosterone concentration was greater for

exposed as compared with control bulls on Day $93(11.9 \pm 0.8$ and $8.2 \pm 0.8 \mathrm{ng} / \mathrm{mL}$, respectively; mean $\pm \mathrm{SEM})$.

\subsection{Age at puberty}

By d 149 of the study, $70.7 \%$ of the exposed bulls and $60.8 \%$ of the controls achieved puberty (Fig. 2), but this difference was not significant. Age, scrotal circumference, body weight, and semen characteristics at puberty did not differ between treatments (Table 1).

\subsection{Breeding Soundness Examinations}

Breeding soundness examinations were completed when bulls averaged $364 \pm 21.5 \mathrm{~d}$ of age (Table 2). The percentage of bulls that passed the BSE was similar (Exposed: 87.8\%; Control: 75\%). Of the bulls that had achieved puberty by Day 149 of the study $(n=51), 47$ passed the BSE (96.1\%) and only two failed (3.9\%; Table 2). Pubertal exposed bulls had a BSE passage rate of $93.1 \%$, whereas only $7.4 \%$ of the exposed bulls that achieved puberty failed the first BSE. Of the control bulls that achieved puberty by Day 149 of the study, 100\% passed their first BSE.

A total of 14 bulls failed the BSE because of inadequate normal sperm morphology or percentage motile sperm. Eight bulls were retested $20 \mathrm{~d}$ after the first BSE. The remaining 6 bulls were not retained in the herd for breeding purposes and thus not retested. Of the eight bulls 
on which BSEs were again conducted, four bulls failed a second time; the primary reason for failure of three bulls was that sperm motility and normal morphology were below the minimum passing standards (30\% motility, 70\% normal morphology). The fourth bull that was retested had white blood cells in the ejaculate and no sperm. Bull age at the time of BSE affected $(\mathrm{P}=0.03)$

whether a bull passed or failed the BSE. Average age of bulls that passed the first BSE was $365 \mathrm{~d}$ and for bulls that failed their first BSE was $353 \mathrm{~d}$. Of the bulls that failed the first BSE, 71\% (10 of 14) were less than $1 \mathrm{y}$ of age, whereas of the bulls that passed the first BSE, $50 \%$ (32 of 63 ) were less than 1 y of age.

\subsection{Behavior assessments}

Bull reproductive behaviors were assessed twice monthly during the study at both estrus and diestrus stages of the female estrous cycle (Fig. 3). Three-way interactions were observed between between treatment, month of assessment, and stage of the estrous cycle for the number of mounting attempts $(\mathrm{P}=0.05)$ and number of flehmen responses $(\mathrm{P}<0.001)$. Considering all months, control bulls tended $(\mathrm{P}=0.07)$ to have more mounting attempts than exposed bulls during diestrus assessments $(0.68 \pm .11$ and $0.38 \pm .11$; mean \pm SEM for exposed and control bulls, respectively) while mounting attempts $(0.96 \pm .11$ and $0.75 \pm .12)$ and flehman responses $(1.40 \pm .24$ and $0.99 \pm .24)$ were similar for exposed and control bulls, respectively) during estrus assessments.

Specifically during months one and two, exposed bulls had more $(\mathrm{P} \leq 0.05)$ flehmen responses (Fig.3, Panel B) when females were in estrus than during diestrus. In contrast, in month four, more $(\mathrm{P}<0.01)$ flehmen responses were observed when females were in diestrus than estrus. Exposed bulls exhibited more mounting activity when females were in estrus 
compared to diestrus in months one $(\mathrm{P}<0.05)$, three $(\mathrm{P}<0.01)$, four $(\mathrm{P}=0.01)$, and five $(\mathrm{P}<$ 0.10; Fig. 3, Panel A).

A month by stage of estrous cycle interaction $(\mathrm{P}<0.001)$ was detected for the number of times that exposed bulls entered the designated cycling beef female area (Fig. 3, Panel C). During months one and three, exposed bulls entered the cow area more times $(\mathrm{P}<0.01$ and $\mathrm{P}<$ 0.01, respectively) when females were in estrus than when females were in diestrus. During month two, exposed bulls tended $(\mathrm{P}<0.10)$ to enter the cow area more times during estrus than during diestrus. In contrast, during month five, bulls entered the cow area more $(\mathrm{P}<0.05)$ during diestrus than during estrus.

\section{Discussion}

Age at puberty of beef bulls in the present study using the criteria of a $\mathrm{SC} \geq 26 \mathrm{~cm}$, and minimum of $50 \times 10^{6} \mathrm{sperm} / \mathrm{mL}$ of ejaculate with at least $10 \%$ progressive motility ranged from 260 to $376 \mathrm{~d}$ and was similar between control and exposed bulls. This range in age at puberty is in agreement with previous researchers [12-14] defining puberty as $50 \times 10^{6}$ sperm in the ejaculate reporting varied age at puberty ranging from 231 to $371 \mathrm{~d}$ and influenced by factors such as breed and weight[12-14].

That prepubertal beef heifers exposed to mature bulls or to bull excretory products attain puberty at a younger age than heifers not exposed to bulls or their excretory products is well documented $[1,15]$ and part of the basis for our hypothesis that bulls exposed to cycling females also would have decreased age at puberty. The females used in the present study were managed such that a group of at least three females were displaying estrus each week. Exposed bulls were able to observe the mounting activity of these females in conjunction with fenceline contact, thus allowing for tactile stimulation. We thought this contact and visualization would be beneficial to 
attainment of puberty because these stimuli have been shown to be important in the process of detection of estrus by bulls [5]. Almquist [8] proved that carefully managed false mounting and a prolonged period of sexual preparation by bulls observing other bulls mounting before semen collection can increase sperm output of beef bulls collected once or twice weekly. Similarly, Geary and Reeves [10] reported that bulls use visualization as the preferred and primary way to detect females in estrus. We visually isolated the control bulls from the females by erecting a plywood barrier that was high enough to completely prevent bulls from having visual and fenceline contact with the females. It is apparent, however, under conditions of the present study that long-term visual and fenceline contact of developing bulls with females exhibiting estrous cycles does not accelerate pubertal onset.

Although prepubertal beef heifers exposed to mature bulls can achieve puberty at an earlier age than unexposed heifers [1], it is not evident that this phenomenon occurs in developing bulls. Our observed lack of influence of cycling females on developing males is in agreement with previous work in pigs [16]. Boars that were penned next to mature, cycling females did not have accelerated pubertal development yet had smaller testes and heavier accessory sex glands at 22 and $30 \mathrm{wk}$ of age and sexual behaviors positively correlated with subsequent mating test scores as compared with boars that were not penned near cycling females [16].

We conducted behavior assessments as potential indicators of any influence that females had on developing bulls. Exposed bulls did not exhibit more or earlier sexual behaviors in response to cycling females than control bulls. Although data were not recorded, it was observed that on the first day that exposed bulls had contact with cycling females, almost all of the bulls stood near the female pen and were extremely active in their homosexual mounting and flehmen 
behaviors. As the study progressed, the incidence of bulls crowding the female pen decreased, as did the occurrence of reproductive behaviors. The number of times that bulls entered the designated cow area during estrus assessments was the greatest during the first month of the study and generally decreased with each subsequent estrus assessment (Fig. 3). It is likely that bulls during the first month found the females to be a novel stimulus. Among exposed bulls, bull interest in the cycling females was greater in month one, as indicated by the number of times they stood near the penned females $(1.36 \pm 0.12$ times per bull in month one during female estrus). In addition, flehmen responses also were greatest during month one when females were in estrus (2.27 \pm 0.34 per bull; Fig. 3$)$.

Before the month three assessments, a new group of estrous females were introduced to replace the females that had been used during the first 2 mo of the study. These females were introduced roughly $30 \mathrm{~d}$ before estrus assessments occurred in month three. Mounting activity of exposed bulls was greatest when females were in estrus during month three, but exposed bulls did not have greater flehmen responses when females were in estrus; in fact, exposed bulls had more flehmen responses when females were in diestrus during month three assessments (Fig. 3). Similarly, exposed bulls entered the designated cow area more when females were in estrus during month three than during diestrus. Increased mounts and time spent in the cow area during month three may be a reflection of the change in females used though assessments were conducted almost a month after the new group of females was introduced, ample time for bulls to adjust to their presence before our observations.

Bailey et al. [17] reported that exposure of mature bulls to novel estrual females for 60 $\min$ at a time elicited a greater sexual behavioral response than exposure to either the same female in estrus or to a female in diestrus. After the introduction of the new females in our study 
during month three, reproductive behaviors either remained relatively constant or decreased. As the study progressed, perhaps the bulls became less interested or more accustomed to the presence of the cycling beef females. Perhaps the introduction of novel estrual females every month would have altered reproductive behavior outcomes to be more similar to those found in Bailey et al. [17]. Generally, the sexual behavior assessed in the present study do not appear to change significantly with pubertal development and though exposed bulls had ample opportunity to interact with cycling females, display of sexual behaviors are not consistently altered by female presence beyond the periods of being a potential novel stimulus.

Puberty in the bull occurs on a continuum of time rather than with one specific event with dynamic changes occurring in the hypothalamo-pituitary-testis axis ultimately driving increased testosterone production and spermatogenesis [18]. In our study, treatment and time interacted to affect testosterone concentrations (Fig. 1). Control bulls had greater concentrations of testosterone than exposed bulls on Day 93 of the study when bulls averaged $294 \pm 21.5 \mathrm{~d}$ of age. The observed concentration for control bulls on this day was the greatest concentration detected in either treatment during the entire study. The reason for the difference at Day 93 and not any other day is unknown. The observed increase in testosterone concentrations with age by both control and exposed bulls and plateau after peak concentrations between Day 65 and 93 (average 265 to $294 \mathrm{~d}$ of age) just prior to puberty is supported by previous studies $[13,19]$ in which mean serum testosterone is basal when bulls are 1 to 4 mo of age, then increases until puberty is achieved and mean serum concentrations remain relatively constant.

A similar percentage of exposed bulls passed their first BSE compared with control bulls. This passing rate and lack of difference between treatments is likely a reflection of exposed bulls not attaining puberty at a younger age than control bulls as a high percentage of both exposed 
(93.1\%) and control (100\%) bulls that had already achieved puberty by Day 149 of the study did pass their yearling BSE. The likelihood of bulls passing their semen evaluation increases with age [20] and poor semen quality, specifically less than $70 \%$ normal sperm morphology is the primary reason for failure of a BSE by yearling beef bulls [20-22]. In our study, bulls ranged in age from 10.5 to $13 \mathrm{mo}$ at the time of first BSE, and age was a significant source of variation in the percentage of bulls that passed. Occurrence of morphologically abnormal spermatozoa in semen is related to SC as bulls with below-average SC [23] had a greater percentage of abnormal sperm and decreased sperm motility and as SC increased the percentage of sperm abnormalities decreased. Our study echoed those findings, because as our bulls developed and SC increased, the percentage of abnormal sperm present in an ejaculate declined. Coe, et al. reported that $96.7 \%$ of bulls aged 8 to $15 \mathrm{mo}$ and with unacceptable SC for their BSE $(<30 \mathrm{~cm})$ produced semen samples with less than $70 \%$ morphologically normal sperm [21]. In the present study, among the 14 bulls (18\%) that did not pass, the primary reason for failure was having less than $70 \%$ normal sperm morphology with exactly half of the bulls that failed the BSE having no normal-appearing sperm in their ejaculates. Of those seven bulls, three had $100 \%$ proximal cytoplasmic droplets which are common in young bulls undergoing puberty [20].

The goal of this study was to reduce the age at which bulls attain puberty by giving them constant, long-term visual and fenceline exposure to cycling beef females, and ultimately increase the percentage of those bulls passing the BSE as yearlings. It is plausible that pheromonal communication still may have occurred between bulls and females even though the two pens of control bulls were located at least $42 \mathrm{~m}$ from the pen of cycling females. Perhaps the distance between the control bulls and the cycling females was not sufficient to eliminate the possibility of pheromones influencing both control and exposed bulls. However, Shipka and Ellis 
$[24,25]$ failed to note a biostimulatory effect of bulls on postpartum dairy cow resumption of estrous cycles despite exposure across a 6 to $8 \mathrm{~m}$ alleyway, indicating need for very close proximity to bulls for a biostimulatory effect to occur in cows. Control bulls in the present study were penned a minimum of $42.7 \mathrm{~m}$ from cycling females, a 3- to 4-fold greater distance between the bulls and cows in the aforementioned study.

Under the present conditions of the study constant, long-term exposure of prepubertal beef bulls to cycling females does not appear reduce bull age at puberty nor ability of bulls to pass a BSE as recommended by the Society for Theriogenology [11]. Females displaying estrus did influence the sexual activity of exposed bulls, but no related effects of sexual behavior were observed in testosterone, age at puberty, or BSE success. From this study, we determined that seedstock producers developing bulls for breeding would see no benefit in age at attainment of puberty or greater BSE passing rates by housing bulls next to cycling females.

\section{Acknowledgements}

This research was supported by the Kansas Agricultural Experiment Station (contribution number 13-037-J). Thank you to Mr. Ryan Breiner, KSU Purebred Beef Unit Manager, Dr. Tom Taul and Sharon Tucker with the Kansas Animal Breeding Services Unit for their collaboration and cooperation on this project. Thank you to Colleen Hill for her expert laboratory and assay work and to all the graduate and undergraduate students for their care of cattle used in this project, behavioral observations, and data collection. 


\section{References}

[1] Roberson MS, Wolfe MW, Stumpf TT, Werth LA, Cupp AS, Kojima N, et al. Influence of growth rate and exposure to bulls on age at puberty in beef heifers. J Anim Sci 1991;69:2092-98.

[2] Berardinelli JG, Joshi PS. Initiation of postpartum luteal function in primiparous restrictedsuckled beef cows exposed to a bull or excretory products of bulls or cows. J Anim Sci $2005 ; 83: 2495-500$.

[3] Tauck SA, Olsen JR, Wilkinson JRC, Berardinelli JG. Duration of daily bull exposure on resumption of ovulatory activity in postpartum, primiparous, suckled, beef cows. Anim Reprod Sci 2010;118:13-8.

[4] Brooks P H, Cole DJA. The effect of the presence of a boar on the attainment of puberty in gilts. J Reprod Fertil 1970;23:435-40.

[5] Rekwot PI, Ogwu D, Oyedipe EO, Sekoni VO. The role of pheromones and biostimulation in animal reproduction. Anim Reprod Sci 2001;65:157-70.

[6] Bigiani A, Mucignat-Caretta C, Montani G, Tirindelli R. Pheromone reception in mammals. Rev Physiol Biochem Pharmacol 2005;155:1-35.

[7] Price EO, Wallach SJR. Rearing bulls with females fails to enhance sexual performance. Appl Anim Behav Sci 1990;26:339-47.

[8] Almquist JO. Effects of sexual preparation on sperm output, semen characteristics and sexual activity of beef bulls with a comparison to dairy bulls. J Anim Sci 1973;36:331-6.

[9] Mader DR, Price EO. The effects of sexual stimulation on the sexual performance of Hereford bulls. J Anim Sci 1984;59:294-300. 
[10] Geary TW, Reeves JJ. Relative importance of vision and olfaction for detection of estrus by bulls. J Anim Sci 1992;70:2726-31.

[11] Chenoweth PJ, Hopkins FM, Spitzer JC, Larsen RE. Guidelines for using the bull breeding soundness evaluation form. In: Theriogenology Handbook, 1993. p. B-10.

[12] Wolf FR, Almquist JO, Hale EB. Prepuberal behavior and puberal characteristics of beef bulls on high nutrient allowance. J Anim Sci 1965;24:761-5.

[13] Lunstra DD, Ford JJ, Echternkamp SE. Puberty in beef bulls: hormone concentrations, growth, testicular development, sperm production and sexual aggressiveness in bulls of different breeds. J Anim Sci 1978;46:1054-62.

[14] Barth AD, Brito LFC. Pubertal development of Bos Taurus bulls. Large AnimVet Rounds 2004;4:4.

[15] Izard MK, Vandenbergh JG. The effects of bull urine on puberty and calving date in crossbred beef heifers. J Anim Sci 1982;55:1160-8.

[16] Nelssen JL, Davis DL, Craig JV, Hines RH. Reproductive development in young boars exposed to sexually mature, nonpregnant sows and gilt. Theriogenology 1982;17:545-50.

[17] Bailey JD, Anderson LH, Schillo KK. Effects of novel females and stage of the estrous cycle on sexual behavior in mature beef bulls. J Anim Sci 2005;83:613-24.

[18] Amann RP, Walker OA. Changes in pituitary-gonadal axis associated with puberty in Holstein bulls. J Anim Sci 1983;57:433-42.

[19] Evans ACO, Pierson RA, Garcia A, McDougall LM, Hrudka F, Rawlings NC. Changes in circulating hormone concentrations, testes histology and testes ultrasonography during sexual maturation in beef bulls. Theriogenology 1996;46:345-57. 
[20] Arteaga AM, Baracaldo M, Barth AD. The proportion of beef bulls in western Canada with mature spermiograms at 11 to 15 months of age. Can Vet J 2001; 42:783-7.

[21] Coe P H. Associations among age, scrotal circumference, and proportion of morphologically normal spermatozoa in young beef bulls during an initial breeding soundness examination. J Am Vet Med Assoc 1999;214:1664-7.

[22] Kennedy SP, Spitzer JC, Hopkins, Higdon III HL, Bridges, Jr WC. Breeding soundness evaluations of 3648 yearling beef bulls using the 1993 Society for Theriogenology guidelines. Theriogenology 2002;58:947-61.

[23] Barth A D, Waldner CL. Factors affecting breeding soundness classification of beef bulls examined at the Western College of Veterinary Medicine. Can Vet J 2002;43:274-84.

[24] Shipka MP, Ellis LC. No effects of bull exposure on expression of estrous behavior in high-producing dairy cows. Appl Anim Behav Sci 1998;57:1-7.

[25] Shipka MP, Ellis LC. Effects of bull exposure on postpartum ovarian activity of dairy cows. Anim Reprod Sci 1999;54:237-244. 
Table 1. No. of bulls reaching puberty by Day 149, mean age, scrotal circumference, body weight, and semen characteristics at puberty for bulls with continuous fenceline exposure to cycling beef females (Exposed) and bulls not exposed to females (Control).

\begin{tabular}{lccc}
\hline & \multicolumn{2}{c}{ Treatment } \\
\cline { 2 - 3 } Item & \multicolumn{2}{c}{ No. (\%) or mean \pm SEM } & P-value \\
\cline { 2 - 3 } & Exposed & $22(43.1)$ & $\ldots$ \\
No. of bulls pubertal ${ }^{*}(\%)$ & $320.3 \pm 5.3$ & $311.3 \pm 5.9$ & 0.28 \\
Age $(\mathrm{d})$ & $34.6 \pm 0.5$ & $34.9 \pm 0.5$ & 0.65 \\
Scrotal circumference $(\mathrm{cm})$ & $466.2 \pm 12.2$ & $437.7 \pm 13.5$ & 0.25 \\
Body weight $(\mathrm{kg})$ & $85.53 \pm 9.6$ & $106.12 \pm 10.8$ & 0.35 \\
Sperm concentration $\left(10^{6} / \mathrm{mL}\right)$ & $45.2 \pm 4.3$ & $34.2 \pm 4.5$ & 0.23 \\
Motility $(\%)$ & $33.8 \pm 4.3$ & $24.8 \pm 4.9$ & 0.17 \\
Normal morphology $(\%)$ & & \\
\hline
\end{tabular}

* Bulls were considered pubertal if they achieved $\geq 26 \mathrm{~cm}$ scrotal circumference and an ejaculate containing $\geq 50 \times 10^{6}$ sperm $/ \mathrm{mL}$ with $\geq 10 \%$ progressive motility. 
Table 2. Pass/fail rates of bulls during breeding soundness examinations (BSE) conducted when bulls averaged $364 \mathrm{~d}$ of age. Bulls were previously exposed to cycling beef females (Exposed) or not exposed to females (Control).

\begin{tabular}{lcc}
\hline Treatment & \% Pass $(\mathrm{N})$ & \% Fail $(\mathrm{N})$ \\
\hline Exposed & $87.8(36 / 41)$ & $12.2(5 / 41)$ \\
Pubertal $^{*}$ & $93.1(27 / 29)$ & $7.4(2 / 29)$ \\
Control & $75.0(27 / 36)$ & $25.0(9 / 36)$ \\
Pubertal $^{*}$ & $100.0(22 / 22)$ & $0(0 / 22)$ \\
\hline
\end{tabular}

Age influenced $(\mathrm{P}=0.03)$ a bull's ability to pass the BSE.

No treatment differences $(\mathrm{P}=0.52)$ were detected in passing rates.

*Includes those bulls considered pubertal by Day 149 of the study. Bulls were considered pubertal if they achieved $\geq 26 \mathrm{~cm}$ scrotal circumference and an ejaculate containing $\geq 50 \times 10^{6}$ sperm $/ \mathrm{mL}$ with $\geq 10 \%$ progressive motility. 


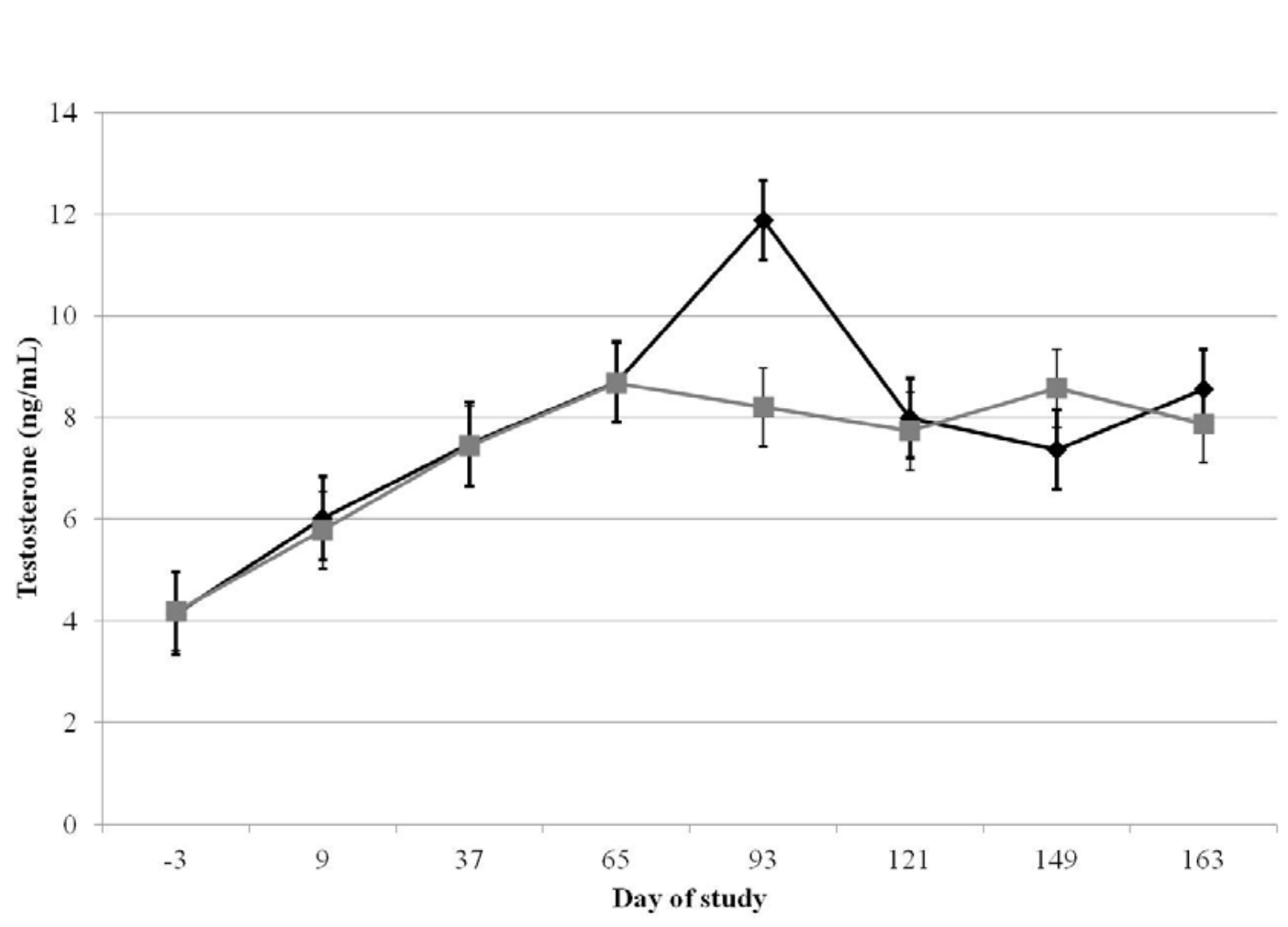

Fig. 1. 
- Control

Exposed

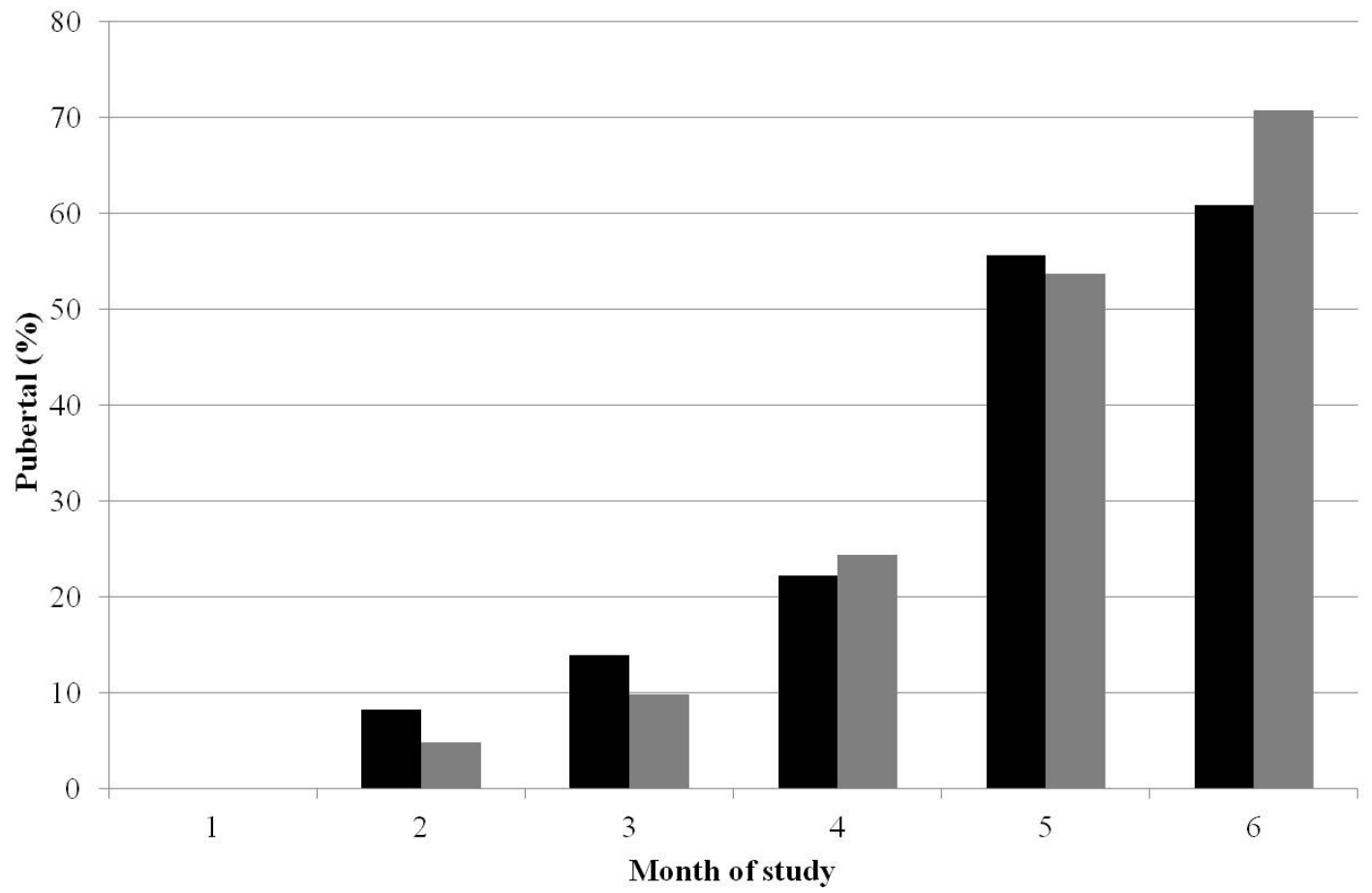

Fig. 2. 

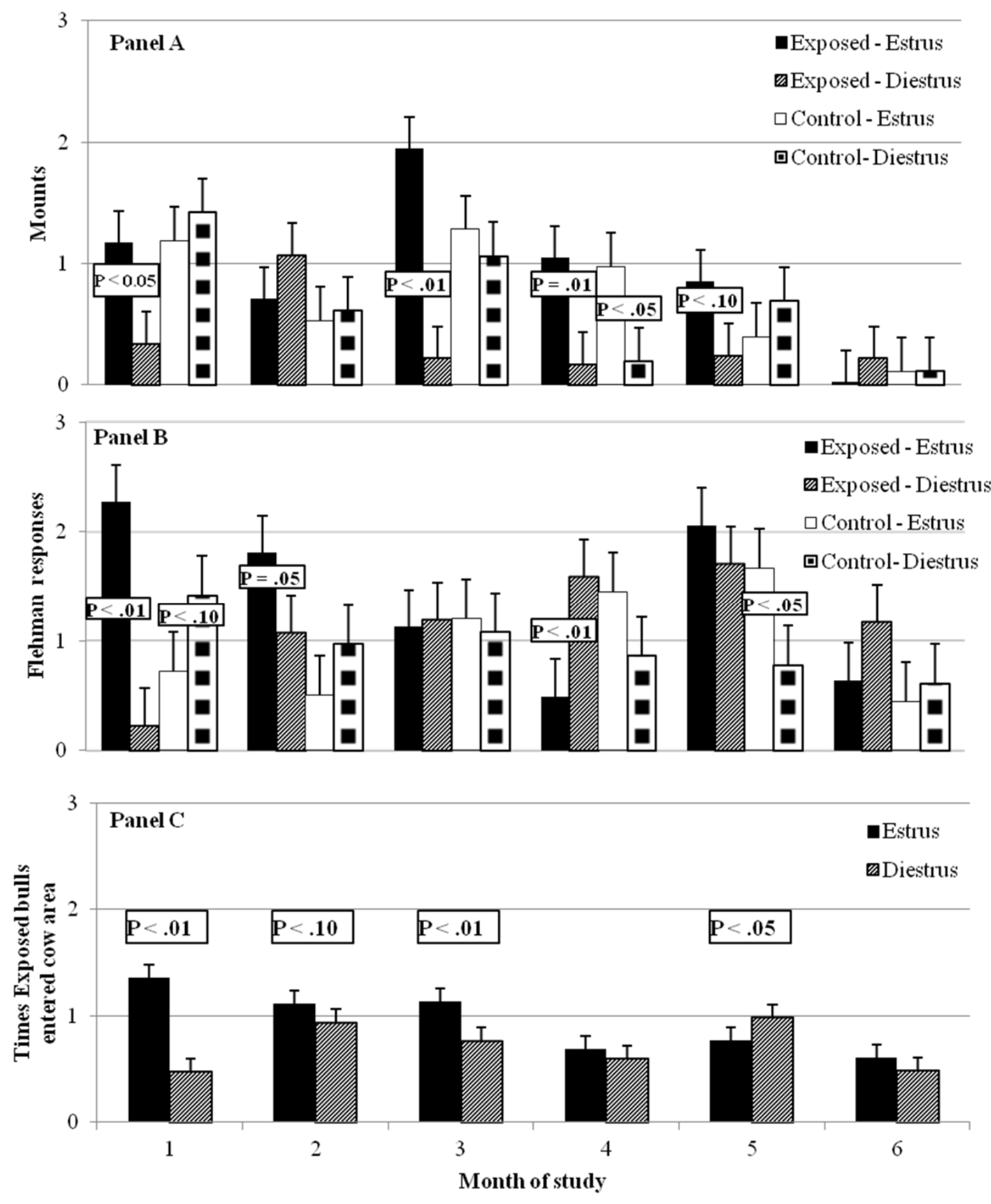

Fig. 3. 
Fig. 1. Mean serum testosterone concentrations for bulls with continuous fenceline exposure to cycling beef females (Exposed) and no exposure to females (Control). A treatment by day interaction $(\mathrm{P}=0.03)$ existed. Serum testosterone concentrations were greater for exposed than for control bulls at Day 93 of the study $(\mathrm{P}=0.002)$. Day 0 was onset of exposure to cycling beef females. Day 163 was the day of breeding soundness examinations.

Fig. 2. Cumulative percentage of bulls achieving puberty each month of the study for bulls with continuous fenceline exposure to cycling beef females (Exposed) and no exposure to females (Control). Percentage of bulls achieving puberty by month 6 did not differ $(\mathrm{P}>0.10)$ between treatments.

Fig. 3. Mean number of mounts (Panel A) and flehman responses (Panel B) per bull exhibited by bulls with continuous fenceline exposure to cycling beef females (Exposed) or with no exposure to females (Control) when females were either in estrus or diestrus. Treatment, month of study, and stage of female estrous cycle interacted $(\mathrm{P} \leq 0.05)$ to affect mounts and flehman responses per bull. Mean number of times bulls entered designated cow area per bull exhibited by Exposed bulls when females were either in estrus or diestrus (Panel C). Month of study and stage of female estrous cycle interacted $(\mathrm{P}<0.001)$ to affect number of times Exposed bulls entered the designated cow area. 